75 years of Agricultural University - Plovdiv

JUBILEE SCIENTIFIC INTERNATIONAL

CONFERENCE Plovdiv 26-28 November 2020
PERSPECTIVES ON AGRICULTURAL SCIENCE AND INNOVATIONS FOR SUSTAINABLE FOOD SYSTEMS

\title{
DOI: 10.22620/agrisci.2021.29.013 \\ CHANGES IN THE VITALITY, LIPID PEROXIDATION AND HYDROGEN PEROXYDE CONTENT OF MAIZE /ZEA MAYS L./ SEEDLINGS DURING CONTROLLED ACCELERATED AGEING
}

\author{
Radoslav Chipilski*, Albena Pencheva \\ Institute of Plant Genetics Resources, Sadovo \\ *E-mail: radotch@abv.bg
}

\begin{abstract}
Seeds from the maize /Zea mays L./ variety Kneja 310 and landrace B0E0170 were subjected to controlled accelerated aging test (AA) for 72 hours and 120 hours at temperature $41 \pm 0.5^{\circ} \mathrm{C}$ and $100.0 \%$ air relative humidity. For the control variant, not subjected to the AA test seeds were used. After AA test, all seed variants were germinated and were used for an analysis of germination energy. The emerging coleoptiles were studied for the presence of anti-oxidative response (MDA, hydrogen peroxide, cell membrane stability), and morphological parameters and relative chlorophyll content were assessed as well as. A vegetation pot experiment was performed with the AA-72h variant and 15-day seedlings were morphologically and physiologically assessed. The aim of the study was to evaluate the relationship between the vitality of the seeds and their stress response to the controlled AA test, which simulated low-temperature storage. The germination rate of seeds and the fresh and dry weight of coleoptiles following ageing treatments were decreased. These results correlated well with the increased accumulation of total hydrogen peroxide and MDA content and the decrease of cell membrane stability. Negative changes were observed in chlorophyll content index, fresh and dry weight and leaf area of 15-day seedlings in pot trial. It was concluded that the controlled accelerated ageing could be used as a model for estimation of seed deterioration in maize after long-term storage.
\end{abstract}

Keywords: accelerated ageing test, maize /Zea mays L./, seed germination, cell membrane stability, oxidative stress.

\section{INTRODUCTION}

Maize is a major cereal crop in Bulgaria. In terms of area and importance among cereals, it ranks second after wheat. Maize is demanding to the conditions of the environment, in terms of heat and moisture (Kiriakov and Gurova, 1969; Dimitrov, 1986; Zarkov, 2001; Nankov et al., 2018). The interest in maize is based on the wide and varied use not only as fodder for farm animals, but also in the food and chemical industries (Vulchinkova, 2000; Vulchinkov and Vulchinkova, 2001; Yordanov, 2004; Valkova, 2006; Glogova, 2007). Compared to other cultivated species, maize has one of the richest reserves of genetic resources, represented by a variety of native species, adapted to specific environmental conditions and used by humans (Böhm et al., 2014). The ex-situ conservation of plant genetic resources in seed gene banks plays an important role for the food security in the future. Seed gene banks manage and maintain genetic resources of the seeds over decades or centuries (Waldren et al. 2000). To avoid frequent rejuvenation of accessions, that is laborious and costly and may cause a loss of genetic integrity, the genebanks aim to prolong seed longevity as much as possible (Engels and Visser, 2003). All seeds are maintained as base 
75 years of Agricultural University - Plovdiv JUBILEE SCIENTIFIC INTERNATIONAL CONFERENCE Plovdiv 26-28 November 2020
PERSPECTIVES ON AGRICULTURAL SCIENCE AND INNOVATIONS FOR SUSTAINABLE FOOD SYSTEMS collection under long-term storage conditions with low moisture content $(5 \pm 2 \%)$ in hermetically closed containers at $-18{ }^{\circ} \mathrm{C}$. Nevertheless, the viability may decrease as a result of deterioration processes. These deterioration processes include: increase in free radical content, changes in protein structure, depletion of food reserves, development of fat acidity, changes in enzymatic activity and membrane damage. The results showed significant differences in the loss of seed viability among species and within the species (Justice and Bass, 1979; Desheva G, 2016). Accelerated aging procedures using high temperature $\left(30-45{ }^{\circ} \mathrm{C}\right)$ and $100 \% \quad \mathrm{RH}$ (Santipracha et al., 1997; Woltz and TeKrony, 2001; Bailly et al., 2002) are used to assess the storage quality in grains for seed vigor and results generally indicate that the tests are adequate for predicting seed viability. Woltz and TeKrony (2000) stated that the accelerated aging test was consistently better than the standard germination tests for predicting seed vigor. Unfavorable storage conditions, especially relatively high environmental humidity and high storage temperature greatly affect the quality of corn seeds (Darabi et al., 2017).

The aim of the study was to evaluate the relationship between the vitality of seeds and their stress response to induced controlled accelerated aging during seedlings phase.

\section{MATERIALS AND METHODS}

Two Bulgarian accessions maize /Z. mays L./ variety Kneja 310 and landrace B0E0170 were used for investigation of the reaction towards accelerated ageing (AA) of their seeds. These genotypes have different productivity characteristics.

Accelerated ageing test (AA) - For the AA test, two replicates (two glasses) of 30 grains per accession were laid on a rack within a sealed glass exicator, which contained $200 \mathrm{ml}$ deionized water to ensure the maintenance of nearly $100 \%$ relative humidity. The glass vessel was exposed to $41 \pm 0.5^{\circ} \mathrm{C}$ for $72 \mathrm{~h}$ and for $120 \mathrm{~h}$, following the International Seed Testing Association protocols (ISTA, 2008). For the control variant, not subjected to the accelerated ageing test seeds were used.

Germination and vigor of seeds after AA test - Germination was evaluated at $22 \pm 0.5$ ${ }^{\circ} \mathrm{C}$, with two replicates of 30 seeds for each AA variant. For the control variant, not subjected to the accelerated ageing test seeds were used. Seeds were sown on two $14.0 \mathrm{~cm}$ diameter Petri dishes, between two layers of filter paper. Afterwards each Petri dish was watered with 20 $\mathrm{ml}$ of distilled, sterile water. The germination was measured on the 5-th day, as a seed was considered to have germinated when the coleoptile had reached a length over $2 \mathrm{~mm}$. The fresh weight, dry weight and length of the plant parts were measured on the 5-th day and on the 15-th day of seedlings development. Fresh weight of coleoptiles and leaves were measured immediately after being cut from plants or seedlings. The dry weight obtained after drying the plant parts at $104{ }^{\circ} \mathrm{C}$ according to Beadle (1993). For that purpose, analytical balance Kern EW 220-3NM was used.

The cell membrane stability (CMS) of the coleoptiles and leaves was determinated following the method by Premachandra et al., (1990). The $100 \mathrm{mg}$ samples of coleoptiles were cut into discs and kept in test tubes containing $10 \mathrm{ml}$ of bi-distilled water in two sets. One set was kept at $40{ }^{\circ} \mathrm{C}$ for $30 \mathrm{~min}$ and another set at $100{ }^{\circ} \mathrm{C}$ in boiling water bath for $15 \mathrm{~min}$ and their respective electric conductivities $\mathrm{C} 1$ and $\mathrm{C} 2$ were recorded. The calculation was done by the following formula: $\mathrm{CMS}=[1-(\mathrm{C} 1 / \mathrm{C} 2)] \times 100, \%$

Lipid peroxidation in coleoptiles was determined by the method reported by Heath and Packer (1968). The results are presented as an accumulation of malondialdehyde (MDA) per unit fresh weight of the mean sample (nmol 
75 years of Agricultural University - Plovdiv

JUBILEE SCIENTIFIC INTERNATIONAL

CONFERENCE Plovdiv 26-28 November 2020
PERSPECTIVES ON AGRICULTURAL SCIENCE AND INNOVATIONS FOR SUSTAINABLE FOOD SYSTEMS
$\left.\mathrm{MDA} / \mathrm{g}^{-1} \mathrm{FW}\right)$. The absorbance of the sample was measured at 600 and $532 \mathrm{~nm}$. The extinction coefficient of $155 \mathrm{mM}^{-1} \mathrm{~cm}$ for calculation the concentration of MDA was used.

Hydrogen peroxide content $\left(\mathrm{H}_{2} \mathrm{O}_{2}\right)$ was measured spectrophotometrically according to Alexieva et al., (2001).

Soil pot experiment - Vegetation pot trial was conducted with seedlings, which were descended from seeds, endured AA test conditions for $72 \mathrm{~h}$. For comparison, not subjected to AA test conditions controls were used. The seeds were sown in pots, which contained $1 \mathrm{~kg}$ dry soil and grown for 15 days in greenhouse under natural light conditions, $25^{\circ} \mathrm{C} / 15^{\circ} \mathrm{C}$ day/night temperature and $40-60 \%$ RH. At the 15-th day after seed germination second fully developed leaves were used for the analyses. Chlorophyll content index (CCI) of the leaves was measured using a portable Chlorophyll Content Meter-CCM 200 plus manufactured by Opti-Sciences, Inc., NH, USA. Measurements were made on two dates for every variant. From each variant, 20 leaves were analyzed by readings from the central part of the leaf $(n=20)$. The morphological assessment of the leaves was carried out in the greenhouse. For determination of the mean values of fresh leaf weight, dry leaf weight and leaf area 10 leaves were used $(n=10)$.

Data are present as a mean value \pm standard error (SE). One-way ANOVA, followed by Fisher test and T-test were used to establish significance of differences between means of the variants.

\section{RESULTS AND DISCUSSION}

The applied controlled AA test conditions for $72 \mathrm{~h}$ and $120 \mathrm{~h}$ on maize grains resulted in a decrease in their vitality. Similar results were reported by Hussein et al., 2012. The seed germination of the two accessions, as well as the growth characteristics of the coleoptiles and roots were significantly reduced at $120 \mathrm{~h}-\mathrm{AA}$ conditions in comparison with the control variant (fig. 1 and fig. 2). Woltz and TeKrony, 2001, established that in maize strong reduction in germination occurred after 96 hours of exposure to AA conditions. In both accessions maximum reduction was reported for fresh weight of the coleoptiles in comparison with the control, respectively $74.0 \%$ for B0E0170 (fig. 1) and $66.0 \%$ for Kneja 310 (fig. 2). The shorter 72 h-controlled AA test did not lead to significant negative reactions in the dry weight of coleoptiles, roots length and seeds germination of Kneja 310. While, similar reactions were reported only for the dry weight of coleoptiles and roots length of B0E 0170 (fig. 1 and fig. 2). Based on these results, it could be concluded that the variety Kneja 310 was more tolerant to $72 \mathrm{~h}$ and $120 \mathrm{~h}$ controlled AA than the landrace B0E 0170.

The cell membrane stability index of the coleoptiles gradually decreased with increasing the duration period of expositions to the AA test. In spite of the obtained strong negative results for both accessions, the variety Kneja 310 (fig. 2) showed more tolerant reaction again, exhibiting a higher value of CMS at 120h-AA test than the landrace B0E0170 (fig. 1). Determination of lipid peroxidation, CMS and hydrogen peroxide content can reveal the deterioration of cells vitality, due to the AA test conditions according to Bailly (2004). Regarding the studied biochemical indices of stress, application of $72 \mathrm{~h}$ of controlled AA test did not reveal larger differences between the two accessions, but disclosed significant differences between the variants. For example, the average values of MDA content and $\mathrm{H}_{2} \mathrm{O}_{2}$ hydrogen peroxide content of coleoptile cells in controlled $72 \mathrm{~h}$ AA conditions were, respectively $370 \%$ and $690 \%$ higher compared to the control variant (fig. 3). These results gave a strong correlation between the positive trend of MDA content and $\mathrm{H}_{2} \mathrm{O}_{2}$ content, and a 
75 years of Agricultural University - Plovdiv JUBILEE SCIENTIFIC INTERNATIONAL CONFERENCE Plovdiv 26-28 November 2020
PERSPECTIVES ON AGRICULTURAL SCIENCE AND INNOVATIONS FOR SUSTAINABLE FOOD SYSTEMS negative value of CMS. Darabi et al., reported severe damage to cells membranes and enzyme activity in maize hybrids varieties seeds, subjected to AA conditions. Coleoptile cells of the variety Kneja 310 expressed a more tolerant reaction towards accumulation of MDA than B0E 0170, because of the accumulated lower MDA compared to adequate control (fig. 3).

The values for the growth characteristics, the chlorophyll content index and the CMS index of the 15-day old seedlings from the preliminarily aged seeds (only $72 \mathrm{~h}$ controlled AA test treatment) are shown in Table 1 and Table 2. The results indicated similar negative growth reactions (tab. 1 and tab. 2), as shown for the $120 \mathrm{~h}$-old seedlings (fig. 1 and fig. 2). Likewise, there was a different reaction between the two accessions reductions of estimated parameters for AA condition variants. A maximal reduction of fresh weight, dry weight and leaf area of the fully developed second leaf compared to the control leaves was found in the landrace B0E0170 - an average of $68.7 \%$ of control (tab. 2). The values of seedlings emergence and the CMS index of the second leaves of B0E0170 decreased significantly and more than Kneja 310 (tab. 2). The variety Kneja 310 did not show strong stress reactions, which was confirmed by the lack of significant differences between the variants (tab. 1), Chlorophyll content index of the second fully developed leaf was reduced to a lesser extent in B0E0170 (91.3\% of control) than in variety Kneja 310 (86.0\% of control).
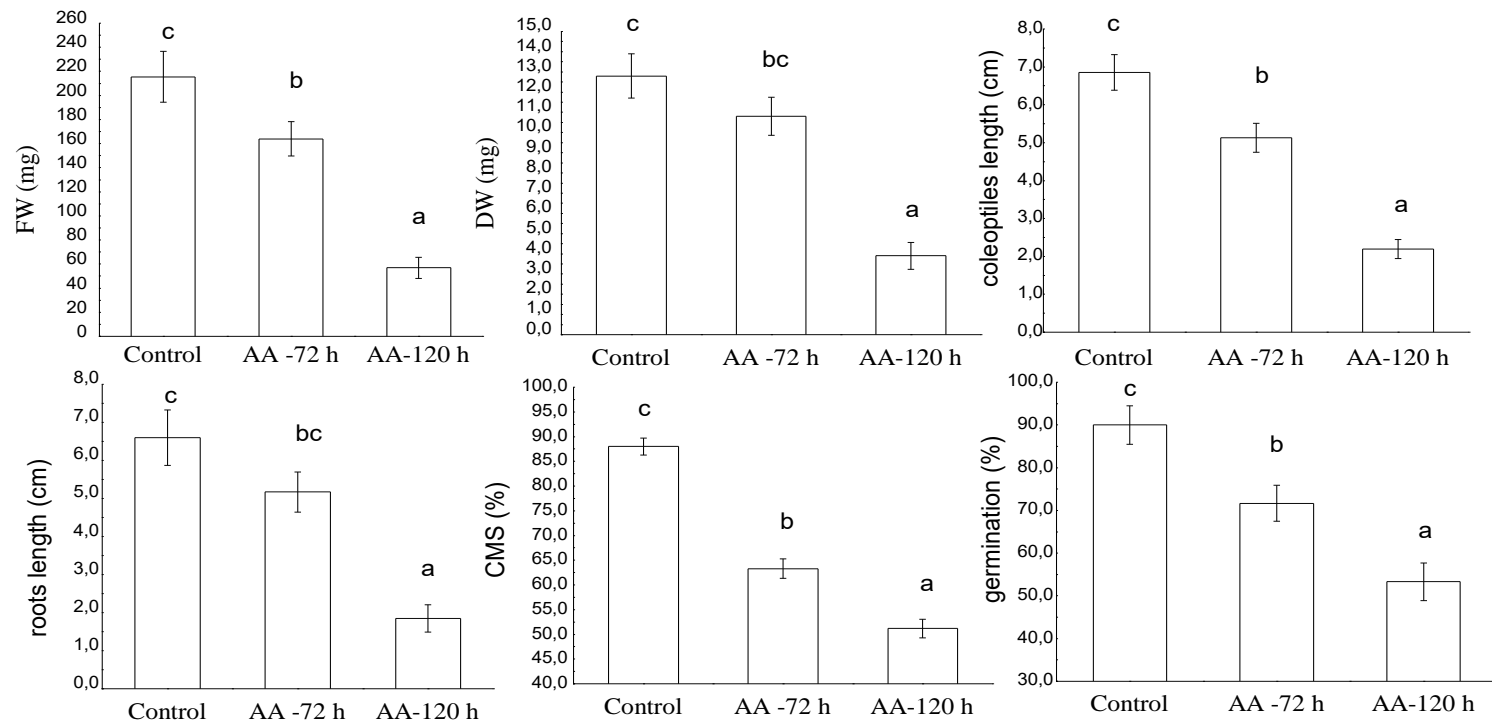

Fig. 1. Morphological characteristics, germination and cells membrane stability of 120 hoursold seedlings of maize landrace B0E0170 originating from seeds subjected to controlled accelerated ageing for 72 hours and 120 hours. Different letters in each column indicate significance difference between application $(\mathrm{P}<0.05$; t-test) 
75 years of Agricultural University - Plovdiv JUBILEE SCIENTIFIC INTERNATIONAL
PERSPECTIVES ON AGRICULTURAL SCIENCE AND INNOVATIONS FOR SUSTAINABLE
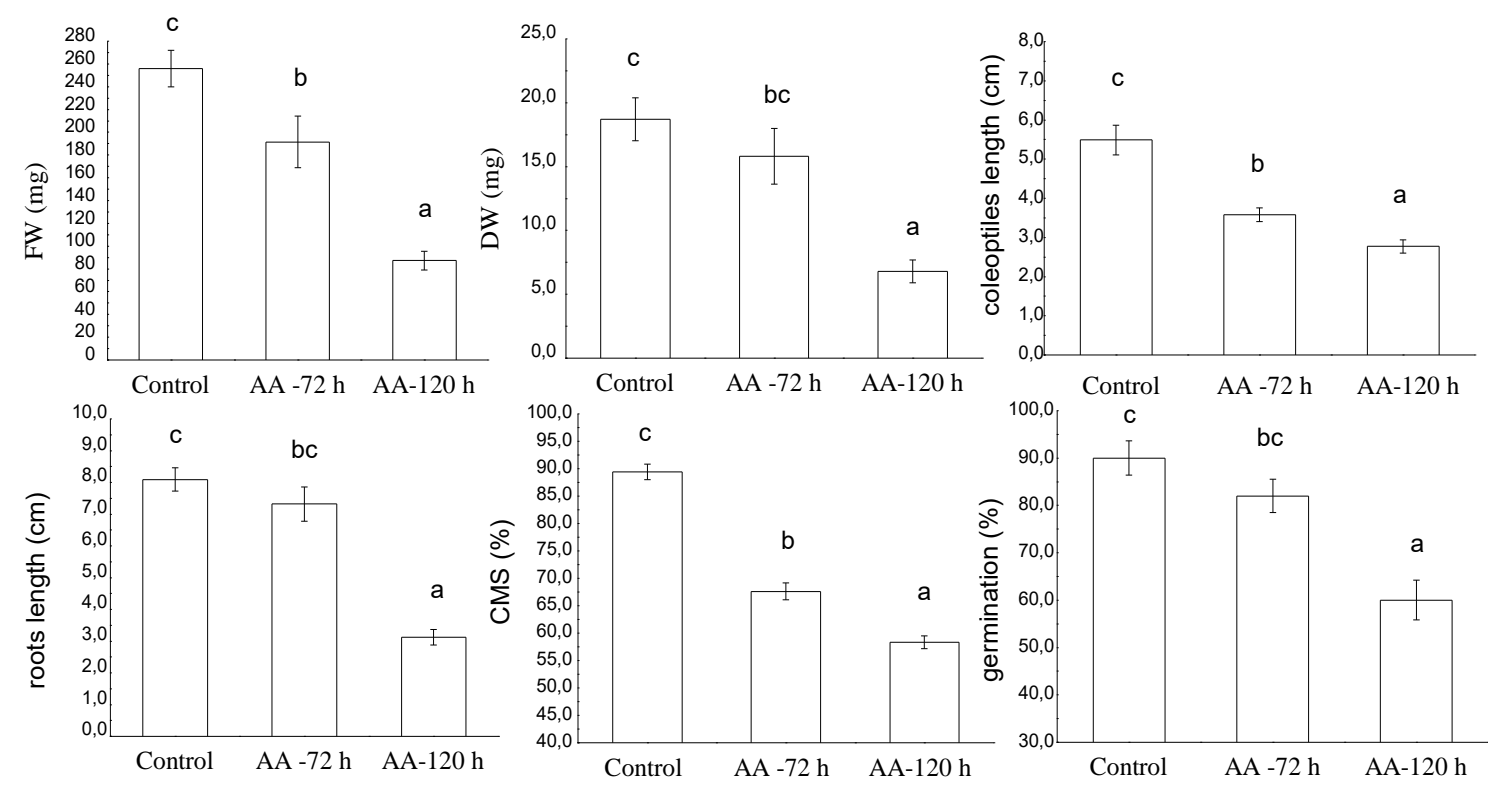

Fig. 2. Morphological characteristics, germination and cell membrane stability of 120 hours-old seedlings of maize variety Kneja 310 originating from seeds subjected to controlled accelerated ageing for 72 hours and 120 hours. Different letters in each column indicate significance difference between application $(\mathrm{P}<0.05$; t-test $)$
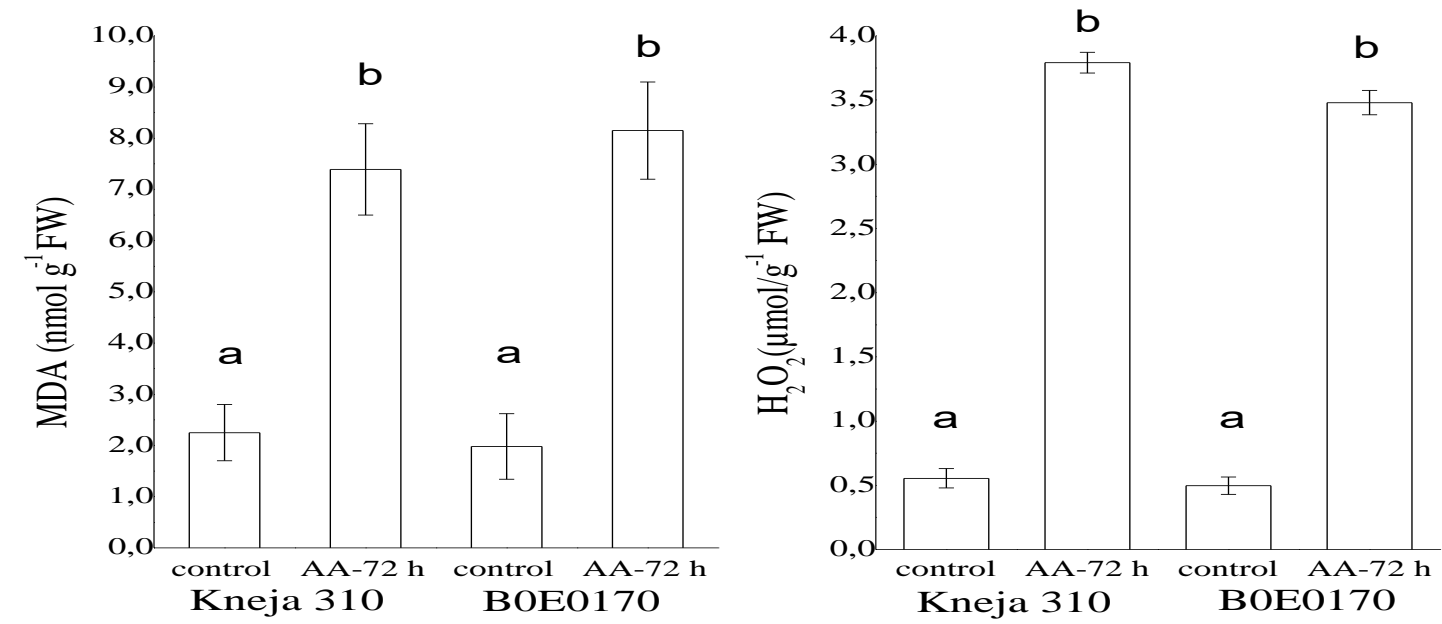

Fig. 3. MDA and hydrogen peroxide content of 120 hours-old seedlings originating from seeds subjected to controlled accelerated ageing for 72 hours. Different letters in each column indicate significance difference between application $(\mathrm{P}<0.05$; t-test $)$ 
75 years of Agricultural University - Plovdiv JUBILEE SCIENTIFIC INTERNATIONAL CONFERENCE Plovdiv 26-28 November 2020
PERSPECTIVES ON AGRICULTURAL SCIENCE AND INNOVATIONS FOR SUSTAINABLE FOOD SYSTEMS

Table 1. Morphological characteristics, germination, chlorophyll content index and cell membrane stability of 15-day old seedlings of maize variety Kneja 310, which grown in pots originating from seeds subjected to controlled accelerated ageing for 72 hours

\begin{tabular}{|c|c|c|c|c|c|c|}
\hline variant & $\begin{array}{c}\mathrm{FW} \\
\mathrm{mg}\end{array}$ & $\begin{array}{c}\mathrm{DW} \\
\mathrm{mg}\end{array}$ & $\begin{array}{c}\text { LA } \\
\mathrm{cm}^{2}\end{array}$ & $\begin{array}{c}\text { CCI } \\
\text { index }\end{array}$ & $\begin{array}{c}\text { emergence } \\
\%\end{array}$ & $\begin{array}{c}\text { CMS } \\
\%\end{array}$ \\
\hline control & $247.3 \pm 15.3$ & $22.6 \pm 3.20$ & $9.30 \pm 0.71$ & $8.56 \pm 0.27$ & $97.0 \pm 2.8$ & $94.9 \pm 3.5$ \\
\hline AA test-72h & $240.6 \pm 12.3$ & $21.2 \pm 1.76$ & $8.38 \pm 0.75$ & $7.36 \pm 0.24$ & $92.3 \pm 3.4$ & $87.2 \pm 3.1$ \\
\hline \% of control & $\mathbf{9 7 . 2}$ & $\mathbf{9 3 . 8}$ & $\mathbf{9 0 . 1}$ & $\mathbf{8 6 . 0}$ & $\mathbf{9 5 . 2}$ & $\mathbf{9 1 . 9}$ \\
\hline LSD 5.0 \% & 27.1 & 2.35 & 0.71 & 0.73 & 10.5 & 2.68 \\
\hline LSD 1.0\% & 38.9 & 5.44 & 0.99 & 0.99 & 14.7 & 4.21 \\
\hline LSD 0.1\% & 57.2 & 12.3 & 1.36 & 1.34 & 22.1 & 7.17 \\
\hline
\end{tabular}

Table 2. Morphological characteristics, germination, chlorophyll content index and cell membrane stability of 15-day old seedlings of maize landrace B0E 0170, which grown in pots originating from seeds subjected to controlled accelerated ageing for 72 hours

\begin{tabular}{|c|c|c|c|c|c|c|}
\hline variant & $\begin{array}{c}\text { FW } \\
\mathrm{mg}\end{array}$ & $\begin{array}{c}\text { DW } \\
\mathrm{mg}\end{array}$ & $\begin{array}{c}\text { LA } \\
\mathrm{cm}^{2}\end{array}$ & $\begin{array}{c}\text { CCI } \\
\text { index }\end{array}$ & $\begin{array}{c}\text { emergence } \\
\%\end{array}$ & $\begin{array}{c}\text { CMS } \\
\%\end{array}$ \\
\hline control & $246.7 \pm 22.8$ & $20.3 \pm 1.84$ & $15.90 \pm 1.34$ & $6.68 \pm 0.24$ & $100.0 \pm 3.2$ & $92.3 \pm 3.2$ \\
\hline AA test-72h & $167.6 \pm 19.3$ & $15.7 \pm 1.59$ & $9.65 \pm 1.35$ & $6.10 \pm 0.26$ & $80.0 \pm 4.4$ & $81.2 \pm 4.8$ \\
\hline \% of control & $\mathbf{6 7 . 9}$ & $\mathbf{7 7 . 4}$ & $\mathbf{6 0 . 7}$ & $\mathbf{9 1 . 3}$ & $\mathbf{8 0 . 0}$ & $\mathbf{8 7 . 8}$ \\
\hline LSD 5.0\% & 51.2 & 4.11 & 1,86 & 0.51 & 12.6 & 3.01 \\
\hline LSD 1.0 \% & 71.4 & 5.73 & 3,98 & 0.69 & 17.6 & 4.73 \\
\hline LSD 0.1\% & 100.0 & 8.03 & 7,27 & 0.93 & 26.6 & 8.04 \\
\hline
\end{tabular}

\section{CONCLUSION}

The germination rate of maize seeds was inhibited after periods of $72 \mathrm{~h}$ and $120 \mathrm{~h}$ of controlled ageing exposure.

The fresh and dry weight of coleoptiles following ageing treatments were decreased and correlated well with the increased accumulation of hydrogen peroxide and malondialdehyde and the decreased cell membrane stability.

Negative changes were found in chlorophyll content index, fresh and dry weight and leaf area of 15-day seedlings descended from aged seeds sowed in pots.

The landrace B0E0170 demonstrated faster aging and worse germination capacity than the variety Kneja 310.

The controlled accelerated ageing could be used as a model for estimation of seed deterioration in maize after long-term storage.

\section{ACKNOWLEDGEMENTS}

This study was carried out with the financial support of the Bulgarian National Science Fund (BNSF) to the project №KP-06M26/2 "Study of anti-stress effect of some growth factors on seeds stored in low temperatures"-2018

\section{REFERENCES}

Alexieva V, I. Sergiev, S. Mapelli, E. Karanov, 2001. The effect of drought and ultraviolet radiation on growth and stress markers in pea and wheat. Cell Environmental, 24, 1337-1344.

Bailly, C., Bogatek-Leszczynska, R. Come, D. F. Corbineau, 2002. Changes in activities of antioxidant enzymes and lipoxygenase during growth of 
75 years of Agricultural University - Plovdiv JUBILEE SCIENTIFIC INTERNATIONAL CONFERENCE Plovdiv 26-28 November 2020
PERSPECTIVES ON AGRICULTURAL SCIENCE AND INNOVATIONS FOR SUSTAINABLE FOOD SYSTEMS sunflower seedlings from seeds of different vigor. Seed Sci. Res. 12: 4755.

Bailly C, 2004. Active oxygen species and antioxidants in seed biology. Seed Science Research, 14, 93-107.

Beadle CL., 1993. Growth Analysis. In: Photosynthesis and Production in a Changing Environment: A Field and Laboratory Manual, (Eds. D.O., Hall, J.M.O., Scurlock, R. Bolharnordenkampfh, R.C. Leegood and S.P. Long), 36-46, Chapman and Hall, London.

Böhm, J., W. Schopprack, V. Mirdita, H. Friedrich Utz, A. Melchinger, 2014. Breeding Potential of European Flint Maize Landraces Evaluated bytheir Testcross Performance. Crop Science, 54, 1665-1672.

Darabi, F., M. Valipour, R. Naseri, M. Moradi, 2017. The Effects of Accelerated Aging Test on Germination and Activity of Antioxidant Enzymes of Maize (Zea mays) Hybrid Varieties Seeds. Iranian Journal Seeds Research, 4(1), 45-59

Desheva G., 2016 The longevity of crop seeds stored under long-term condition in the National Gene-Bank of Bulgaria, Agriculture, 62, 2016, 3, 90-10

Dimitrov, D., 1986. Influence of irrigation, mineral fertilization and number of plants per unit area on the productivity of self-pollinated maize lines. Influence of irrigation, mineral fertilization and the number of plants per unit area on the productivity of self-pollinated maize lines. Proceedings of Jubilee Conference "100 years of agricultural education, 120 years of experience in Bulgaria", Sofia, 160-165 (Bg).

Engels JMM, L. Visser, 2003. A Guide to Effective Management of Germplasm Collections. IPGRI Handbooks for Genebanks No. 6. International Plant
Genetic Resources Institute, Rome, Italy.

Glogova, L., 2007. Analysis of the structural elements of the yield of experimental maize hybrids. Proceedings of the National Scientific and Technical Conference with International Participation, Stara Zagora, 1, 345-348 (Bg).

Heath RL, L. Packer, 1968. Photoperoxidation in isolated chloroplasts I: Kinetics and stoichiometry of fatty acid peroxidation. Archives of Biochemistry and Biophysics, 125,189-198.

Hussein, H., A. I. Shaheed, O. Yasser, 2012 Effect of accelerated aging on vigor of local maize seeds in term of electrical conductivity and relative growth rate (RGR). Iraqi Journal of Science, 53(2), 285-291.

ISTA (2008) International rules for seed testing. International Seed Testing Association, Bassersdorf

Justice O.L., LN. Bass, 1979. Principles and practices of seed storage. London, UK: Castle House Publications Ltd

Kiriakov K., M. Gurova, 1969. Maize. Soil and climatic zoning of the main field crops. Bulgarian Sciences Academy, Sofia, 94 $-100(\mathrm{Bg})$.

Nankov M., L. Glogova, M. Lakova, 2018. Results of the study of the structural elements of the yield of experimental maize hybrids. Proceedings of the National Scientific and Technical Conference with International Participation "Ecology and Health", ISSN (2367-9530), 108-112 (Bg).

Premachandra GS, H. Saneoka, S. Ogata, 1990. Cell membrane stability an indicator of drought tolerance as affected by applied nitrogen in soyabean. Journal of Agricultural Science, 115, 63-66.

Santipracha, W, Q. Santipracha, $\quad$. 
75 years of Agricultural University - Plovdiv JUBILEE SCIENTIFIC INTERNATIONAL CONFERENCE Plovdiv 26-28 November 2020

Wongvarodom, 1997. Hybrid corn seed quality and accelerated aging Seed Science and Technology, 25, 203-208

Valkova V., 2006. Influence of crop density on the yield of maize hybrids Kn 625 and Kn M625. Proceedings of the National Scientific and Technical Conference with International Participation, Stara Zagora 1, 299-302 (Bg).

Vulchinkov S., P. Vulchinkova, 2001. Productive and adaptive capabilities of original and modified formulas maize hybrids. I Grain yield, stability parameters and accompanying indicators. Anniversary scientific session "50 years of DAI", I: 199 (Bg).

Vulchinkova P., 2000. Physiological and genetic studies of elements of productivity and yield of maize. $\mathrm{PhD}$ Thesis, 99-121 (Bg).

Waldren S., J.R. Martin, T.G.F. Curtis, A. O'Sulivan, 2000. Genebanks and biodiversity conservation: the Irish threatened plant genebank project. In Rushton, B.S. (Ed) Biodiversity: the Irish dimension. Dublin Royal Irish Academy, 135-147.

Woltz, J.M., D.M. TeKrony, 2001. Accelerated aging test for corn seed. Seed Technology, 23 (1), 21-34

Yordanov, G., 2004. Analysis of the general and specific combinatorial ability for grain yield of early inbred maize lines. Proceedings of the National Scientific and Technical Conference with International Participation, Stara Zagora, 2,108-110 (Bg).

Zarkov, B. 2001. Influence of meteorological conditions on grain yield from maize grown under non-irrigated conditions. Plant science, 38, 208-212 (Bg). 